\title{
Understanding Identity and Socio-Culture Milieu in Sri Lankan Refugee Camp: A Study of Anuk Arudpragasam's The Story of a Brief Marriage
}

\author{
Rincy Saji \\ Research scholar \\ Centre for research in English \\ Maharaja's College \\ Mahatma Gandhi University \\ Ernakulam, Kerala, India \\ rin4.rins@gmail.com
}

"But woe to him who is alone when he falls for he has no one to help him up."

Ecclesiastes 4:10. Human beings- man defined as the animal rationale, distinct us from other animal species in nothing but the additional attribute to reason. But the modern science proves that "men share all other properties with some species of animal kingdomexpect that the additional gift of 'reason', which makes man a more dangerous beast."(On Violence, 62). But from the moment, humans began living together in communities, some of their members were forcibly expelled from those first towns and villages on ethnic, religious or other grounds. The practice of helping such people absconding became one of the earliest hallmarks of civilization. The world is beating a path to those refugee camps ever since. And in the twentieth century to systematize with these situations the international community took fundamental stride to codify the assistance. Since the Second World War each year, hundreds of thousands of people around the world are forced to move to uncertain places from their safe havens. The United Nations High Commission for Refugee defines them as "A refugee is someone who has been forced to flee from his or her 
country because of persecution, war or violence." According to Hannah Arendt, an American-German philosopher, in her seminal essay "We Refugee" published in 1943 defines a refuge as a person driven to seek refugee because of some act committed or some political opinion held. But she also adds these people who had to seek refugee neither committed any acts nor most of them even dreamt of having any political opinion. We are all brought up in the conviction that life is the highest good and death the greatest trepidation but if we take a close look within the refugee camps, the lives hailing there, we come to know that they have lost the horror for death. Instead of fighting or thinking about how to fight back they have got used to wishing death to friends or relatives and if somebody dies, they cheerfully image all the trouble they have been saved from. As per the report of United Nations High Commissioner for Refugees (UNHCR), in 2019, 70.8 million of people are displaced in our world fleeing war, persecution and conflict, at the end of 20182.3 million more were forcibly displaced. This is the highest number UN refugee agency has seen in its 70-year existence. Then there are the Internally Displaced People, who have left their homes but remain inside the country borders which numbers 41.9 million. Then there are children every second refugee is a child. These are not just number but souls in flight.

South Asia, is unique in many ways it is one of the world's most complex regions with multi-ethnic societies, characterized by striking internal divisions along linguistic, regional, communal and sectarian lines, but externally linked to one another across national boundaries. This place remains the hotbed in which intense identity politics have culminated in ethnic conflicts. In ordinary language, at least, one can use "identity" to refer to personal characteristics or attributes that cannot naturally be expressed in terms of a social category, and in some contexts certain categories can be described as "identities" even though no one sees them as central to their personal identity. Nonetheless, "identity" in its present incarnation reflects and evokes the idea that social categories are bound up with the bases of 
an individual's self-respect. As a concept has existed from the beginnings of human civilization. In ancient times, groups or communities were constituted on the basis of kinship ties Anthony D.Smith, in his seminal work, Ethnic Origins of Nations, published in 1986, says that Ethnie are nothing but the historical communities built up on shared memories. A sense of common history unites successive generations, each with its set of experiences which are added to the common stock, and it also defines a population in terms of experienced temporal sequences, which convey to later generations the historicity of their own experiences. But when coming to a diverse nation with multi-ethnic groups hailing in the land, the question of identity with regard to religion, origin, language etc comes in and the land becomes an open space for this very identity struggle. And this paper examines particularly, perhaps one of the longest civil war South Asia has witnessed, the Sri Lankan civil war (1983-2009) as we mentioned earlier people flee from their homes in fear of conflicts, persecution or war attracting international attention. The very concepts of exile or displacement are the traumatic events faced by the refugees. The refugee experience of trauma can be generally divided into three distinct phases, first is the pre-displacement phase, the home that is violently assaulted; next is the displacement phase where the refugee will flee their country and the journey towards new uncertain destinations, this expedition in itself brings in the greatest traumatic events. Lastly is the post-displacement phase, the experience of people now living in a new country as a refugee, a status often pervaded with feelings of non-belonging.

The focus of this paper will be on the study of Anuk Arudpragasam, born in Colombo, Sri Lanka, debut novel The Story of a Brief Marriage published in 2016, expounds the human sufferings and trauma in graphic details. The Sri Lankan government's strict media blackout during the final stage of the three decades long civil war left the world largely unaware of those civilians caught in the crossfire between the army and the insurgents of the Liberation Tigers of Tamil Eelam (LTTE) in the northeast of the island. The novel published 
seven years after the war's brutal ending, sheds light on this very chapter of Sri Lanka's recent history of violence, which resulted in the deaths of more than 100,000 people, with at least tens of thousands are said to have perished in the last months alone. Shyam Selvadurai, author of Funny Boy, comments that "it bears witness to the lives and suffering of thousands of men, women, and children who perished in the last days of Sri Lanka's civil war, whose numbers are still uncounted and who lie in unmarked graves." The protagonist, Dinesh, introspection remains the heart of the novel. He is a young man not long out of school, hiding near a civilian camp, trying to survive and to dodge the recruiters. The novel opens in medias rex where from the first line- "Most children have two whole legs and two whole arms" it's clear that the identity of a man with his all bodily parts are things from the past. The scene narrates Dinesh carrying a six-year old boy who has already lost his right leg and is in a condition to lose his right arm. The graphic account of how the doctor amputees the boy's right arm with a kitchen knife. This shows" there were no surgical instruments in the clinic, no anaesthetics, neither general nor local, no painkillers or antibiotics." (The Story of a Brief Marriage, 2). But as the narration goes the doctor conducts the surgery with the kitchen knife "not with quick effective strokes but with a jagged, saw like motion." Even while observing these brutality in the camp, Dinesh contemplates not the violence but whether it would have been better if the boy had lost his left arm (and not the right) to support his "already amputated thigh" (2) on the same side with a set of crutches. Refugee camps, especially in their emergency phases, are places where everything seems to be similar, repetitive, and modular. The camps become the shelter to all those displaced and effected people in the war, irrespective of their caste, economic status they share the same space, where they share a collective identity. Yet the traumatic experiences of people living in camps during the war experiencing the hard reality such as the jarring impact of the war, loss of native land, loss of loved ones, the experience of violence, the remembering and issues of reconciliation all these leave a great mark on their health and consciousness. Dinesh is 
assigned with the duty of disposing the body part and on the way to dispose the right arm we can see the setting of the camp, the novels details the scenario of the camp through the narrator's eyes -“there were plenty of naked body parts scattered around the camp of course, fingers and toes, elbows and thighs, so many nobody would say a thing if he just left the arm under a bus or beside a tree."(5).

In a site where hours of day is deduced by hearing the sound of shelling, a land "glazed by layer of smooth red slime" where one has to take heed steps to not land on any splayed hands and feet the author tries to depict the assault done not only to the human body but to the human consciousness. Every time they makeshift camp they think" that the area was safe and that the army would never be able to take it, they had come in desperation at last to the camp." The people in these camps have lost their fear on death, like the Dinesh who awaits death either "be killed in shelling, or conscripted and then killed on fighting." Any of these ways' death is certain. The notion of identity is the traits and characteristics, social relations, roles, and social group memberships that define who one is. But here in spite of surrounded by countless number of people Dinesh couldn't remember the last time "he'd really felt connected to somebody else." (11) He couldn't even remember what it is like to spend time with another person. In this war-torn nation, the question of culture social life is at question. Dinesh, is "like a leaf detached from the tree" without any attachment to living things. He remains "indifferent to these things". He couldn't even remember what it is like to spend time with another person. But Anuk Arudpragasam has not failed to embrace the sublime beauty of love in the stark cruelty of war. As the title of the novel denounce its end. In a milieu of war, bloodied land and broken body the narrator takes us to the terrible beauty of world's grandeur concept of marriage. Mostly in societies Marriage is an alliance between a man and woman often based on the notion of love, tough not always sometimes codified as a social institution, in legal, economic, social and spiritual ways. Though marriage ceremonies, rules and roles may differ from one society to another, marriage is considered a 
cultural universal which means that it is present as a social institution in all culture. The character of Ganga, who is also working in the clinic of the refugee camp. It is a socially construct belief that it is the father who should be the one to protect his family, had failed to do so and by this act of marriage he is passing his duty off into someone else. Here in the novel the character, Mr. Soumasundaram proposes the hand of his only daughter after her brother was killed two weeks before. He was trying to" marry his daughter to any male of marriageable age he could find." (8) The parents were desperate to get their children married because in this point married people were less likely to be conscripted into the movement. But the situation has changed tremendously that during the last resort of the civil war married as well as the unmarried were just as likely to be recruited for the fighting. Dinesh thoughts had shifted for the first time since the proposal, in Ganga's direction realizing the fact that he would die soon and accepting this marriage means spending his last few days" with a person, with not just a person but with a girl, with a woman, a wife."(35) According to Ganga, this act of marriage "would make no great difference to her safety."(45) But she accepts the proposal for his sake. As the title of the novel predicts, in this atmosphere of danger, it is inevitable that the marriage will be brief. Yet in a setting like this no ceremonies, rules, socially constructed norms of religion, economic status, education, etc is of no matter ,'To tie a thaali you only need the blessings of the bride's parents...in circumstances like this we don't have to worry about anything else.' (52)

Under these circumstances, every act, no matter how routine, becomes an event, magnified and intensified in Dinesh's mind. Defecating, urinating, eating, crying, and even breathing require heightened awareness. His thoughts on these daily acts of life consist the major part of the novel. Dinesh was unaware of the act of speech for a long period that he started to wonder on "if they couldn't talk about their pasts, what they could say to each other at all, given no future for them to speak of either". This very thought troubled him as he was used to be silent for a long time. People in the camp talked less; there was a profound silence 
all over the camp. They communicated for "food and medicine, shared news about fighting, information about missing people." In ordinary life people always talk to each other, but here in camps they "didn't feel like talking." Anuk delineate the simplest act of communication as strenuous task in the backdrop of a refugee camp. His contemplation on the act of speech goes as "Conversation was a fragile thing after all, like a plant that grows only in rich, warm, nourishing soil...perhaps there existed only a narrow range of conditions under which human conversation could flourish."(66) Unlike the ordinary people the people in refugee camps "sit silently alone, lost inside them, unable, in any way, to connect."(67)

Anuk comprehends the minute to minute threats people face in the camp like the shortage of food, which is one of the prime needs. "Most evacuees were eating less than a single meal a day." (64) The prices were high for the food supplies. "A kilo of rice was already almost a thousand rupees." The act of eating was a memory from the past Dinesh thought "it was strange to think that his right hand was used also for eating." (72) The lost rhythm of eating was recovered to him when Ganga offered him some dal and rice. The act of eating has become a mere phenomenon.

After their marriage, Dinesh thought keeping himself clean so that Ganga would be attracted to him. The basic human need of keeping himself clean was a tedious task for Dinesh as it was a long time, he had not known the tenderness of water. -"it was tough as though, with the washing away of all the matter that had encrusted his body...he had freed himself of the hold the recent past had taken of him...the present made free finally to take on a different significance, his raw new skin ready, at last, for new memory and for new life.”(123).

During the Sri Lankan civil war, like the other aspects of life, sexual behaviour and attitudes were also affected by the conflict. The narration exemplifies that "they were married now. In a way, it was only natural for them to have desire, to want to satisfy them for the first time," (145), but the long loss connection to the world and to himself they couldn't 
consummate their love and we can see that Dinesh ends in crying for the first time in the novel. He couldn't even tell the urge inside him to cry for a long time. "the drops of salty water secreted by the ducts in his eyes felt like just the smallest part of a vast lake buried somewhere deep inside him, like a massive dam that had sprung a tiny, silent leak."(118) He couldn't remember having cried even when his mother had dies" (150) and finally was able to connect with himself after a long time, "crying for yourself...it was a way of taking care of yourself,...even if it involved some pain.”(151).

Most of The Story of a Brief Marriage_consists of slow, meticulous descriptions of Dinesh's thoughts and feelings during his one day as a husband. They try to make a shared life and their efforts produce the novel's most moving material. Never mind, the constant probability of death, wounding, forced conscription, starvation and rape: Ganga and Dinesh are shy, uncertain and tentative - just as any other sudden new young couple would be. The prospect of a 'peaceful' future is only toyed with allegorically through Ganga and Dinesh's marriage. But given away as early as in the novel's title, the story of their marriage is brief. As fighting intensifies in one of the final days of war, Ganga is killed by the end of the narrative. "as though unable to believe that blood was no longer moving through her body," (190) Driven by an innate human desire to not die alone, the power of the novel resides in the affective register of how Dinesh perceives the world around him. His hope to find "somewhere in desolation" an instrument by which the spilled blood could be collected, out back in Ganga's body, and set once more in motion. But the mere act of breathing inevitable to hold on to life. We can see as Dinesh contemplate on the act of breathing," the heart only beat because of the blood's movement around the body, and not, in fact, the other way around." (190). 
Yet within the short duration of narration seems to encompass a lifetime. Rather than destroy Dinesh, the minute-to-minute threats make him profoundly cognizant of the fragility, sanctity, and beauty of life. Young Dinesh also has a tendency to ponder all with the flair of an educated philosopher rather than a high school student battered by war. Still, these are forgivable missteps. This is a war that dislocated a nation, irrespective of ethnicity, but the most helpless were the poorest Tamils, caught behind battle lines, prevented by the rebels from leaving, whose choice was "either be killed in the shelling, or conscripted and then killed in the fighting."

Arudpragasam gives those innocents a place in history as ordinary citizens, with dreams and belief in salvation, who holds on to privacy, dignity, pride and ritual. He makes it impossible not to stand skin-to-skin with them as they huddle in fragile dugouts, their refuge found beneath overturned boats and their scant belongings like paperweights that hold them on earth. The novel with its raw but tender prose that so eloquently examines the fault lines of human existence.

The United Nations General Assembly in the resolution 55/76 on $4^{\text {th }}$ of December in 2000 started celebrating World Refugee Day annually on $20^{\text {th }}$ of June to support millions of families all over the world who have lost their homes and dear ones because of violence or war. As global trends in forced displacement show, there is but one path forward. We must act together, our solidarity across societies will power change and promote solutions and give refugees a chance to aspire to a better future. 


\section{Bibliography}

Arendt, Hannah. On Violence. Harvest Books, 1970.

Arudpragasam, Anuk. A Story of a Brief Marriage. Flatiron Books, 2016.

Peter Gatrell, 'Refugees_-what's wrong with history?', Journal of Refugee Studies, vol. 30, no. $2,2017,170-89$ (178).

"What is a Refugee? Definition and Meaning | USA for UNHCR" (2018). Unrefugees.org. Retrieved 30 August 2019, from https://www.unrefugees.org/refugee-facts/what-is-arefugee/ 